\title{
THE LOCAL TRADITION OF MAGICAL PRACTICES IN BANTEN SOCIETY
}

\author{
Ayatullah Humaeni \\ Faculty of Tarbiyah and Adab at IAIN "SMH" Banten \\ Telp.081911036305, email:ayataditya@yahoo.com
}

\section{Abstract}

This article aims to discuss the cultural phenomenon of magical practices in the Muslim society of Banten which still exists up to the present. It is a part of my MA thesis research that has been combined with my recent field research using ethnography method based on the anthropological approach. Magical practices becomes cultural identity for Bantenese society. Several sources on Banten mention that Banten as a central spot for magical sciences, besides it is also well-known as a religious area. The magical practices are still regarded important for Bantenese people, especially who live in the villages to solve their practical problems in their social life. Magic is a socio-religious phenomenon which has long, well-established roots in Banten society. It is traceable from many literatures that describes the uniqueness of Bantenese's culture. Besides other magical practices debus is the most noticeable appearance of the magical tradition in Banten since the sultanate period until nowadays. The existence of debus Banten and other kinds of magical practices in Banten has strengthened the reputation of Banten as if 'a haven of magical sciences'.

Tulisan ini mencoba mendiskusikan tentang fenomena kultural mengenai praktek magis pada masyarakat Muslim Banten yang masih ada hingga saat ini. Artikel ini merupakan bagian dari tesis Master saya yang sudah dikombinasikan dengan penelitian lapangan baru-baru ini dengan menggunakan metode etnografi berdasarkan pendekatan antropologis. Praktek magis sudah menjadi identitas kultural bagi masyarakat Banten. Beberapa sumber menyebut Banten sebagai pusat ilmu-ilmu gaib, di samping dikenal sebagai daerah yang religius. Praktek magis masih dianggap penting bagi masyarakat Banten, khususnya yang tinggal di pedesaan untuk menyelesaikan masalah-masalah praktis dalam kehidupan sosial mereka. Magis adalah sebuah fenomena sosio-kultural yang 
memiliki akar yang cukup lama dan sudah berakar kuat dalam masyarakat Banten. Hal ini bisa dilacak dari banyak literatur yang menjelaskan keunikan dari budaya Banten. Debus adalah bukti paling kongkrit dari tradisi magis di Banten sejak periode kesultanan hingga saat ini, disamping beragam praktek magis yang lainnya. keberadaan debus Banten dan berbagai jenis praktek magis yang lainnya di Banten telah memperkuat reputasi Banten sebagai 'tempat bersemayamnya ilmu-ilmu magis'.

Key words: magic, local tradition, Banten

\section{Introduction}

The image of Banten as the religious area and as the central spot of magical practices has been widely well-known not only by Bantenese society itself but also by many people outside Banten. Many literatures and the research records on Banten, more or less often deal with the reputation of Banten as the central spot of magical practices. In this regard, Martin van Bruinessen on his book 'Kitab Kuning, Pesantren dan Tarekat: Tradisi-Tradisi Islam di Indonesia' calls Banten as 'a heaven of the occult sciences' (Martin, 1995:176).

The tradition of magical practices can be traced both from literature works of Banten and from the practices of this cultural phenomenon in Banten up to the present day. Many religious figures such as kyai hikmah and ahli hikmah in Banten teach and practice ilmu hikmah (magical science) to help Bantenese society in solving their practical problems. Many people believe in the kyai's supernatural power that can help them to reach their purposes and to solve their problems by using kyai's magical power. Because of his capability in Islamic knowledge and in magical sciences, the kyai of Banten has respectable and high position in the society. Several Arabic texts (kitab) as the sources of their ilmu hikmah make society believe that magical power of kyai is allowed in Islamic teaching so that they will be avoided from shirk.

Furthermore, there are also many pesantren in Banten, especially the salafy pesantren, which not only teach Islamic knowledge, but also teach magical sciences. Ilmu sambatan, ilmu kontak, ilmu hadiran, ilmu kebal, hizb are several representatives of magical sciences practiced and taught in these places. In some occasions, several pesantren in Banten conduct a religious ritual in which in this event there is a tradition of giving several ilmu hikmah to the santri and non-santri who are actively involved in this ritual tradition.

Debus, the cultivation of invulnerability to fire and sharp metal objects, is the most conspicuous representative of the magical tradition in Banten since 
the sultanate period up to the present. Debus teachers engage in whole range of magical practices. Their techniques are an eclectic blend of Muslim and pre-Islamic magic, their sacred formulas including Islamic Arabic invocations alongside Javanese and Sundanese language formulas (Martin, 1995: 187-8).

The strong reputation that Banten as the central spot of magical practices may be traced in the various sources written by both the local writers and the International researchers. For instance, Sartono Kartodirdjo on his work describes how several religious figures who led the revolt distributed a kind of amulet (jimat) and the holy water (air keramat) to their followers before starting the rebellion in order to be safety and success in attacking their enemy. (Kartodirdjo, 1966:235). The similar actions were also conducted by several kyai or ustadz in the communist revolt of Banten in 1926. Michael Charles Williams on his book clearly stated that before going on the rebellion, several kyais who became the leaders of the revolt distributed the invulnerability (ilmu kekebalan), amulets, as well as the holy water to their followers (Williams, 1982: 372).

Several theses on magic in Banten written by some local writers have strengthened such an image that magic has apparently become the cultural identity of Banten society. Tihami's thesis discusses the function of magic as a tool of legitimation for kyai and jawara to be informal leaders in the village. He states that in desa Pasanggrahan, a kyai will be considered as a leader if he has supernatural power (Tihami, 1992:5). Furthermore, Helmy's thesis also deals with magic in Banten from the ontology point of view. He states that the practices of magic reflects the philosophical view of human's thought (Helmy, 2004: 236). Discussion on magic also becomes a research focus of Humaeni's thesis 'The pehnomenon of Magic in Banten Society', written in Leiden University in 2009 (Humaeni, 2009: 45-63). Moreover, Nitibaskara also writes the practices of black magic in two of villages in Banten. He explains how the social prejudices for the witches and the sorcerer were given by the Bantenese society in 1985-1990 (Nitibaskara, 1993:54-76)

This article tries to discuss several traditions of magical practices in Bantenese society, especially about ilmu hikmah, ngelmu in pesantren, the magical power of pawang, bone-stters, and dukun, the magical tradition of debus and other magical practices that have been ever existed in Banten.

\section{The Tradition of Ngehikmah (Magical Practices) in Banten}

Ngehikmah is a Bantenese term generally referred to magical sciences 
practiced by kyai (religious teachers), especially kyai hikmah or ahli hikmah. Based on my field research, there are many kyai, either who have a pesantren or not, not only teaching Islamic knowledge, but also teaching magical power. The kyai who teaches magical power (ilmu hikmah) in Banten is frequently called kyai hikmah or ahli hikmah. Many people come to his house or his pesantren only for asking his help to cure certain diseases or asking several magical sciences. In this regard, K.H.J.M, one of kyai hikmah from Padarincang Banten, states,

Almost everyday many people, from both around his village and outside Banten, come to my house for many purposes; some of them ask him to cure some deseases, some of them ask amulets (jimat or wafaq) for obtaining good jobs, good careers, good positions; some of them ask him to insert susuk for appearing dignity, bravery, and good-looking aura; Indeed, they ask me pelet, a magical power to make somebody love him/her (K.H.J.M, 2010).

Based on his statement above, it is clear that many Bantenese society still believe in magical power of kyai hikmah or ahli hikmah. Some of Bantenese society prefer visiting kyai hikmah to solve their practical problems to visiting doctors or using their reasons.

Kyai are informal leaders in Bantenese society. They are considered the community's leaders because of several superior qualities. Kyai are regarded as community leaders when they are able to serve the community's need concerning religion. He must have charisma and authority; both of these characteristics may be obtained by practicing magic cited from religious sources. Since the majority of Bantenese society believes that there are supernatural aspects in religious doctrines which can be used to meet their practical needs, such as curing diseases, evoking authority ect, Kyai as those who have the authority to interpret and transmit religious knowledge, are then supposed to be able to use magical formulae taken from some verses of the Qur'an. The trust of the Bantenese people in the kyai's capability to do so, according to Tihami, is made use of by several kyais to legitimate and maintain their leadership in the community (Tihami, 1992: 175-181).

In connection with this, Zamakhsyari confirms Tihami's view mentioned above. He states that a kyai can be a charismatic leader because the community believes that a kyai has spiritually superior skills which make it so that a kyai can give karomah and barokah for his followers. However, this belief works only as long as the kyai is wira'i (a man who always refrains from shubhah, from all conduct prohibited by Islam); capable of avoiding contemptible actions both 
in the view of Islamic law and according to social norms (Dhofier, 1995:70-71). It seems that the behavioral aspects are crucial for a kyai to be a charismatic leader.

From the explanation above, it seems that a kyai is recognized and well-respected by the community not only because of his comprehensive understanding of religious knowledge and his good behavior and morals, but also because of his mastering of the occult sciences (ilmu gaib) and the use of it for the community's interests.

Dealing with kyai hikmah in Banten, in the twentieth century, there were two very famous kyai hikmah from Banten. The first one was Ki Amin (KH. Muhammad Hasan Amin) from Cibuntu near Pandeglang (d.1988), the second one was Ki Dimyati from Dahu in Cadasari (north of Pandeglang). Besides being well-known as kyai hikmah, both of these kyai were also famous as tarekat teachers. The former was a tarekat teacher of Qadariyyah and the latter taught hizibs of tarekat Syadziliyah. 'Numerous stories were telking about both of these kiais' miraculous powers, their clairvoyance, the rapid careers or sudden riches that befell some of those who had won their favours.' (Martin, 1995: 279-282).

Nowadays there are many kyai from Banten who practice ilmu hikmah, such as K.H. J.M. (Serang), K.H. Fayumi (Serang), K.H. Maksum (Serang), K.H. Enjang (Pandeglang), Salman Farisi (Serang), Yahya Ibn Ma'mun (Serang), Abah Sakin (Serang), Ahmad Abbas bin Ma'mun (Serang), Ubing Al-Maraghi ZA (Pandeglang), and Anis Fuad (Serang). They are well known as kyai who posses and practice magical powers used for helping the community's practical needs. Many visitors, both from around and from outside Banten, come to their houses to ask for charms, amulets, wafak and other things for various purposes.

There are many kinds of magical practices performed by kyai hikmah or ahli hikmah in Banten. Aside from curing diseases, relieving possessed people and expelling evil spirits from the body, several of them also practice and provide susuk, ilmu kebal (invulnerability), pelet, wafak or mantera (magical formula) for trading, getting a job and a good position. Indeed, in the village elections, almost all candidates use their magical power to try to win the elections. Many politicians also come to kyai hikmah or ahli hikmah for various purposes.

Several classical Islamic texts are used as the sources of ilmu hikmah in Banten. To mention some ilmu hikmah sources are Syams al-Ma'arif wa Lathaif al-Awarif and Manba' Ushul al-Hikmah of Imam Ab al-Abbas Ahmad bin Ali 
Al-Bani, Mujarrabat al-Dairab (Fath al-Malik al-Majid al-Muallaf li naf' al-'Abid) of Sheikh Ahmad al-Dairab, Khazanah al-Asrar Jalalah ah-Adzkar of al-Sayyid Haqi al-Nazili Syumus al-Anwar wa Kunüz al-Asrar of Ibn al-Haj al-Tilimsani alMaghribi, Al-Jawahir al-Luma'ah fi Istihdhar Mulük al-Jin fi al-Waqt wa al-Sa'ah of Syekh 'Ali Ab Hayyullah al-Marzüqi, Dalail al-Khairat of Imam Ab 'Abdillah Muhammad bin Sulaiman, al-Aufaq of Imam al- Ghazali, Tashil al-Manafi' fi al-thib wa al-Hikmah of Syekh Ibrahin bin Abd al-Rahman al-Azraq, Al-thib al-Nabawi of syekh Muhammad bin Ahmd al-Dzahabi, al-Rahmah fi al-Thib wa al-hikmah of Syekh Jalaluddin Abd al-Rahman al-Suyüthi. Al-Sir al-Jalil fi Khawaddh Hasbunallah wa ni'mal-Wakil of Sayyid ab al-Hasan al-Syadzli (Ahmad, 2005:109-110 and Humaeni, 2010: 86).

Dealing with the way or method in obtaining ilmu hikmah, there are three methods to obtain ilmu hikmah: the first one is by inheritance, when a kyai hikmah teaches his ilmu hikmah to one or several of his children; the second one is by learning it from other kyai hikmah or kyai tarekat. The third one is by reading ilmu hikmah sources (kitab) and self-study (Ahmad, 2005: 94-96). Indeed, a kiai hikmah sometimes carries out a great event at a certain time and place to give ijaza of ilmu hikmah consisting of many hizibs, wafaq, amalan and other magical formulas. In this event, santri and non-santri who want to obtain this ijaza should pay a sum of money as mahar (Humaeni, 2009: 94-96).

If we observe the explanation above, magic belongs to religious element. It is asserted by Koentjaraningrat's view that the system of magical science constitutes one of the special elements of religious system, besides the religion itself (Koentjaraningrat, 1998:204). According to him, the system of magical science, in many cases, is often similar to system of religion. Magical science, as system of religion, also recognizes conceptions and its teaching, the magicians and their followers, the sacred places and times, and the techniques that should be done by the performers.

The belief in the supernatural powers of certain religious figures is actually not only prevalent in Banten, but also in Java. Rafless remarks that 'every Arab from Mecca, as well as every Javanese people who had returned from a pilgrimage thither, assumed on Java the character of a saint, and the such persons supernatural powers.'(Raffles, 1978: 3). As a result, they were well-respected by the community; it was not difficult for them to influence and to boost the spirit of society to fight against the Dutch interests. In this regard, from the story of Banten we know that many kyai, together with other elements of Bantenese society, performed many insurrections to fight against 
the Dutch colonial government and native authorities who were considered to be agents of the Dutch. To provoke the uprisings, many kyai or hajis made use of their magical power; they even distributed amulets (jimat) and air suci (holy water for salvation or invulnerability) to their followers. For instance, $\mathrm{KH}$. Tubagus Ismail, one of the leaders of Banten's revolt in 1888, was believed to be a sacred saint who had ilmu kebal and was able to manifest himself in different faces and shapes (Djajadiningrat, 1996: 49). Sartono describes how in the morning of 10 July, 1888 one of the leaders of the peasants' revolt, Haji Mohamad Asik, ordered his followers who gathered together in great numbers at Bendung in Banten 'to drink holy water in order to make them invulnerable in battle.' (Dijk, 2005: 17). Furthermore, some religious teachers involved in the communist revolt of Banten in 1926 were arrested and exiled to Boven Digul because of several reasons; they urged their followers to fast for several days and anointed them with holy water to make them invulnerable; they also sold amulets to their followers (William, 1982: 69-79).

\section{The Kinds of Magic in Banten Society}

Generally speaking, magic is functionally classified into two kinds; white magic and black magic. The former is a kind of magic used to bring benefit and happiness to people, while the latter is used to wreak havoc and bring illness, and to invoke disadvantage and misery on society. However, nowadays this classification is no longer used by anthropologists because the idea of good and bad, right and wrong, fine and evil, advantageous and disadvantageous, beneficial and useless is relative. It means that something is probably regarded as good, fine, advantageous, or beneficial by some people, but not by the others. The line between those concepts is blurred. Indeed, in a society, one kind of magic is sometimes used for two purposes, good and bad.

Even though anthropologists no longer use the terms black magic and white magic, these terms are more common than other terms for Bantenese people. Bantenese people call 'white magic' as ilmu hikmah, otherwise 'black magic' is often called 'ilmu rawayan'. They believe that magic derived from kyai, ahli hikmah, and pesantren must be quoted from the Qur'an, hadith, and some Islamic classical texts (kitabs). For instance, when K.H.J.M. (K.H.J.M., 2008) would give magical science (ilmu gaib), wafak (magical formula written on paper, animal skin, cloth and other materials used for talismans) and amulets to his students or commoners, he would cite kitab Samsu al Ma'arif, Mambail Ushulu lil al Hikmah, Abu Basyar al Falaqi, Aufaq Imam Ghazali, and others 
as his sources. Hence, many Banten people believe that magic derived from religious figures is white magic (ilmu hikmah) because it aims for the happiness and welfare of people, or at least, in the view of KH. Ma'sum Daenuri, its formula, its rite, its techniques and its purpose are not in contradiction with Islamic law (syari'ah).(Maksum, 2010). On the other hand, magic derived from non-religious figures, such as sorcerers, witches, fortune-tellers, etc, of which the formula, rite, and meaning are not quoted from the Qur'an, hadith, or kitab, and which is directed toward the suffering and misery of other people, is often regarded as black magic (ilmu rawayan), or at least, it is not allowed by Islam or it is called, in the term of Burgel, 'illicit magic (as-sihr al-haram)' (Burgel, 1988: 31).

Concerning black magic, there are two common terms widely recognized by Bantenese society: teluh and tenung (witchcraft and sorcery). Both kinds of magic often become a hot issue when someone has a disease that cannot be detected by a doctor or treated with modern medical. In connection with the technique and the way of practicing teluh (sorcery), there are several kinds of teluh recognized in Banten, i.e. teluh angin, teluh banyu, teluh geni, teluh penjarahan and teluh celuruh.

Teluh angin is a kind of sorcery where the technique and the media the sorcerers (dukun teluh) use to harm and to kill their victims are the use of several devices such as needles, nails or spikes, broken glass or porcelain, and such kind, which are packed into a bag or a doll and hung on the tree using a black string. They say incantations to deliver their magic to the victims, using wind or air to deliver it. This action is done repeatedly until they are sure that their victims die. Teluh banyu is almost the same as teluh angin, but the media they use to deliver their magic is water. They usually put magical things into river, well or a glass of water of their victims. Both teluh angin and teluh banyu are also called teluh rambat because both of these sorceries are meant to kill the victims slowly. Moreover, teluh geni is the most dangerous black magic in Banten because the effect of such magic is faster than other kinds of sorcery (teluh). The victims who suffer from this kind of teluh will die in a few days, even a few hours. This teluh uses a little knife or magical kris which is put into a full water glass or bowl. The objects, then, are covered by clothes and the sorcerers say some incantations to these objects. After saying the incantation, the glass cover is lifted. If the knife or keris is no longer in the glass, it means that the victims will suffer from this action in a few minutes, even die a few hours later. Teluh penjarahan is a kind of sorcery which uses certain cemeteries 
as media to harm the victims. The sorcerers will ask the evil spirits living in these eerie places to assist them to kill someone else. Teluh celuruh is the least dangerous kind of black magic. It aims not to kill the victims, but to make them suffer from itching all over the victims' body so that the victims will scratch their body continuesly until it becomes ulcerous which cannot be cured. One who suffers from this teluh will not be recovered by a doctor unless the sorcerer himself stops his action or someone else, such as a kyai, ahli hikmah, or dukun who has supernatural powers does it. This teluh may use wind, water, cigarettes, cloth and other objects as media to deliver black magic to the victims. These kinds of black magic, according to Nitibaskara, still existed and became hot issues in the community of Banten during 1985-1990 (Nitibaskara, 1993: 229-231).

Based on the practical goals, Firth classified magic into three types. They are productive magic, protective magic, and destructive magic. (Firth, 1958:12425). Firth's classification above can also be applied in the case of Bantenese magic. For instance, many people such as salesmen, politicians, businessmen, etc., ask wafak, charms, and amulets (jimat) from kyai, ahli hikmah, even from dukun in order to achieve their goals. These are examples of productive magic in Firth's sense of the word which exists in Banten. Furthermore, many Bantenese people also come to kyai, ahli hikmah, and dukun to avert misfortune, to secure safety while travelling and to cure their illness, whether it is caused by black magic or not. It means that to protect their life, they still believe in magic. This is protective magic in terms of Firth's categorization. Finally, I can also give examples of 'destructive magic' which can be found in Banten. The practice of sorcery and witchcraft (teluh and tenung) in the sub-districts Sajira and Bojonegara in Banten show us that Bantenese are also well acquainted with its destructive magic.

\section{Several Ngelmu in Pesantren of Banten}

I have observed that many pesantren in Banten, especially the salafi pesantren, teach ilmu gaib (magic) at certain times, usually on Thurday night and on the $10^{\text {th }}$ day of Muharram. There are several kinds of magical practices performed by santri under the supervision of senior santri, ustadz or kyai. Sambatan, ilmu hadiran, ilmu kontak and ilmu kekebalan (invulnerability) are the popular magical practices which are often learned and practiced in pesantren.

Ilmu sambatan (one type of magical practice) is the magical action of inviting any spirit to enter into their body, either the spirit of an animal such 
as a tiger, monkey, snake, etc; or the spirit of a person who has died and is considered to possess supernatural power, such as a saint, kyai, buya; or the spirit of people who are masters in self-defense art (silat), such as Bruce Lee. To perform this magic in practice, the santri read khadarat to the Prophet and his company, Sheikh Abdul Qadir Jaelany, Sultan Hasanuddin, etc; then they read surah al-Fatihah, syahadah, sholawat, and istighfar three times, and after that they close their eyes and focuse their mind on what kind of spirit they want to invite. While they are praying in their heart, they are spelling the word 'hadir. hadir. hadir' (Hadir means 'be present.' It is the antonym of 'be absent.') continuously until they are convinced that the spirit has entered into their body. If they called the spirit of a tiger, they will act as if they are a tiger, and if they called the spirit of Bruce Lee, they will act as if they are Bruce Lee, and so forth. Finally, to finish the practice of this magic, they read the sentence 'laa haula walaa quwwata illa billahi al-alliyil adhiim' (there is no power except that of the almighty God). This magic can be performed individually or collectively.

Ilmu hadiran is almost the same as ilmu sambatan, but the spirit which they invite to come into their body is never the spirit of an animal. They usually invite the spirit of a saint, kyai, or their religious teachers who have died. The formula recited and the methods they use to invite the spirit are almost the same as for ilmu sambatan. However, ilmu hadiran is usually performed by at least two people, in which case one of them acts as the performer who is be entered by the spirit, and the others act as santri who are not entered by the spirit. The latter could ask many things to the former, considering that he has been entered by the spirit completely.

Furthermore, ilmu kontak is a kind of magical practice performed by at least two people, with the purpose of hitting the body from a distance. It is also used to hold back the body blow from others.

Ilmu kebal (the science of invulnerability), according to Cees van Dijk, is 'akin to the practice of magic both white and black.' (Dijk, 2002:18). It is, in my opinion, similar to debus. However, while debus nowadays is performed for entertainment or as a traditional art performance, invulnerability (ilmu kekebalan) studied in pesantren aims to protect the santri from the danger either when they are still living in pesantren or afterleaving it. Apart from the definition stated by Cees van Dijk above in which ilmu kebal can be used both for white and black magic, ilmu kebal as learned in pesantren is meant for good purposes. Santri are usually even warned by their kyai not to use it for bad purposes. 
However, in practice, some of them sometimes use it for bad ends.

To obtain ilmu kekebalan from kyai, santri is usually given two options: 'mateng' or 'mentah.' The first one means that the santri does not have to do any fasting and wirid, he just gives a sum of money to the kyai as a form of mahar. Mahar here means a sum of money or things which have to be given to the kyai, ahli hikmah, or dukun as a condition to obtain magic. The second one means that santri must fast for several days (There are several types of fasting to possess ilmu kebal. The first is fasting as performed in Ramadan, but the numbers of the days are different, sometimes three, seven, or forty days. The second is puasa mutih, fasting in which one may not eat anything except rice and water when he breaks the fast in the evening. The third is puasa mati geni. It means that santri has to stop eating anything, stop talking with anyone, from morning to the next morning or for twenty four hours) and perform wirid for a certain amount of time.

In this regard, on every $10^{\text {th }}$ day of Muharram, Kyai Payumi, a kyai of pesantren Darul Ulum in Padaricang, Banten, usually invites santri who stayed in his pesantren as well as from outside, to perform a congregation of wirid which begins at $09.00 \mathrm{pm}$ and lasts until 02.00am. After performing wirid, then he enters into his special room and calls the santri, one by one, to come into his room. In this room, he gives some ilmu gaib (magical science) to the santri, and one of them was ilmu kebal (invulnerability). However, even though all santri perform wirid at that time, not everybody can obtain ilmu gaib from him. He does not give it to everybody. He just gives it to certain people whom he considered being the proper people to possess it. Before giving this ilmu kebal, while reciting $d z i k i r$, he usually holds the right hand of the santri. If he sees that the santri is the proper person to possess it, he recites a wirid and rubs the santri's hands, and after that he takes a sharp big machete (golok), and slashes the santri's hands repeatedly. After he is sure that the santri succeeds in performing ilmu kebal, he advises his santri not to use it for bad purposes. However, if he considers the santri to whom he would give ilmu kebal not the proper person to possess it, after holding the santri's right hand he just gives him a glass of water over which a prayer $\left(d o^{\prime} a\right)$ has been recited. This is the sample of ilmu kebal mateng obtained without fasting. However, on the $10^{\text {th }}$ day of Muharram event, though santri could obtain ilmu kebal mateng, the kyai doesn't ask a certain sum of money as mahar. However, if a santri intended to give it, the kyai would not refuse it. It is an annual activity conducted in his pesantren.

el Harakah Vol.14 No.1 Tahun 2012 
Besides some of the magical practices I mentioned above, pesantren in Banten also teach wirid in the form of hizib for magical ends, taken from kitab Dalail Khairot. There are some hizibs which kyai sometimes gives to a certain santri, such as Hizib Nashr, Hizib Bahr, Hizib Ikhfa, Hizib Jailani, Hizib Yamani, Hizib Autad, Hizib Khafiy, Hizib Barqi and Hizib Nawawi. Hizib Nashr is used to treat crazy people, to cure someone who is possessed by a spirit (kerasukan setan/jin), and to cure epilepsy. It is also used for invulnerability and for holding back of belting at a distance (ilmu kontak). Hizib Bahr is practiced in order to be respected by others, in order to have authority (wibawa), and also for invulnerability. Hizib Ikhfa is aimed to smash the enemy, to protect oneself from danger, and for invulnerability. Hizib Jailani is aimed to be compassionate and loved by others, and for invulnerability. Hizib Yamani is aimed to cure various illnesses. Hizib Autad is aimed to achieve a wish easily, Hizib Khafiy is practiced in order to be safe from those who want to wound us, to get respect from others, and to have authority (wibawa), Hizib Barqi is meant to snarl the enemy, to make the enemy blind and deaf, etc. Hizib Nawawi is aimed to various purposes. (K.H.A.S.,2009 and Thaifuri, 2003: 46-82).

Such kinds of magic are often practiced in traditional pesantren in Banten. For instance, Mashadi, when he became a santri in pesantren al-Halimy in Barugbug, Banten, he had obtained one hizib, namely hizib Khafy, from his kyai. His kyai asked him to observe puasa mutih for seven days, and at the same time he also had to recite the formula of hizib khafiy 41 times every night. $\mathrm{He}$ said that after he had finished performing the ritual, he felt more confident and he felt that many people favored and loved him. (Mashadi, 2010).

Moreover, a kyai who leads pesantren 'Sabilu Rosyad' in Banten stated that the magical science (ilmu gaib) he teaches his santri was derived from several Islamic classical texts (kitabs), such as Samsul Ma'arif, Mambail Ushulu lil al-Hikmah, Abu Basyar al-Falaqi, and Aufaq Imam al-Ghazali. He said that he usually teaches some kinds of magic to his santri once a week or once a month. Ilmu kontak (magic for self-defense), ilmu lengket (magic for protecting property from robbery), ilmu merendam (magic for love), and ilmu aurad qolbu dinar (magic for obtaining money easily) are the kinds of magical science he taught his santri. (K.H.J.M, 2009). Indeed, he also provides susuk (several small pieces of gold or diamond inserted in the face or another part of the body as a magical charm to improve one's beauty, power and etc) and amulets (jimat) for those who need them. In 2009, he offered me a little kris which can be used for many purposes because of its magical power. 


\section{The Magical Power of Pawang and Bone-Setters in Banten}

The society of Banten also recognizes the supernatural power possessed by pawang. Pawang is someone endowed with magical powers. He is considered capable of stopping or moving rain, and he also can be an animal tamer. They are often used by society on certain occasions, such as wedding parties, circumcision parties, slametan, and even for national events. For instance, when Banten province was appointed to be the host of Musabaqah Tilawatil Qur'an National XXII (National Contest of Qur'anic Recitation) on 24-27 June 2008, the governor of Banten ordered the committee to prepare pawang hujan as many as possible during the performance in order for the agenda to go well. The committee, therefore, prepared twenty pawangs for this event. (Radar Banten Online, 2008: 1). On another occasion, PLTU (the electric power station) of Suralaya, Cilegon Banten, invited some pawangs to catch or to chase away three crocodiles which were hanging around the turbine, because they were worried that the crocodiles could destroy the turbine. (Radar Banten Online, 2007:1). Even though after several days there was still no result, this shows that the existence of pawang is much needed by local society, by both educated and uneducated people.

Aside from the belief in the supernatural powers of pawang, the society of Banten also confers its trust upon magical powers possessed by spirit-masters, bone-setters, masseurs, magicians, etc. For instance, there are two famous bone-setters in Banten; H. Supriyadi in Tapos, Tiga Raksa, Tangerang, and Mas Jaya in Baros, Serang. They often cure patients who come not only from Banten, but also from other areas of Indonesia and even from other countries such as Germany, the Netherlands, Japan, Malaysia, Nigeria, etc. H. Supriyadi admits that he obtained his magical powers from his teacher, K.H. Samaun, being witnessed by Buya Mukri (1860-1959) -one of the kyai tarekats who were actively involved in the communist revolt of 1926 in Banten and was said to have much karomah and magical powers. H.Supriyadi affirmed that he was convinced to practice his magical abilty after observing wirid al-Waqi'ah, which he obtained from K.H.Samaun. (Ali,2007:81-82). Many Bantenese people prefer curing their bone fractures at H. Supriyadi or Mas Jaya's places rather than having it done in the hospital.

\section{A Magic Tradition of Debus in Banten}

J. Vredenbregt defines debus as 'a performance the manifest function of [which] is to furnish proof of invulnerability.' (J. Vredenbregt, 1972: 302). 
Hamka describes debus as walking on utensils made of glass or porcelain (Hamka,1980:156), and Umari defines debus as a miraculous skill to stand in ecstasy while suffering from a piece of sharp iron which is used to hurt the body or an awl used for mystical self-injury (Umari, 1977:116). The definitions stated by the experts above show great similarity concerning debus. All of them see debus as a performance of invulnerability by using sharp metal objects.

There are various opinions about the origin of debus in Banten. One opinion states that it first emerged in Aceh at the same time as the dissemination of Islam in this region. The performance received much attention from local societies because they had never seen anything like it before. It was said that generally debus was performed by propagators who spread Islam into the region as a means to attract attention from society in order to aid conversion to Islam. After debus had developed in Aceh, it spread outside Aceh through West Sumatra, and finally came to Banten after many changes that had to do with the local situation and conditions in the new area (Hadiningrat, 1982:32). However, this opinion is contrary to another one that states that debus in Banten did not derive from deboih in Aceh, but it originated from Banten as a development of silat (martial arts) 'al-madad,' (Al-madad is an art performance to furnish proof of invulnerability. The name al madad refers to its founder, shaikh Saman Al-Madad. Shaikh Saman is one of the saints whose protection is invoked by certain- but not all- performers of debus Banten. A folk dance called Saman, that is perhaps based on the lively dhikr or ratib of the Sammaniyya used to be performed at feasts and parties, often along a show of silat (martial arts) and dabus (Bruinessen, 1995:184). However, even though tarekat Samaniyah had existed and developed in Banten, but it is not clear how this tarekat was spread in Banten (Abrori, 2004:181-215) which also appeared at the same time as the dissemination of Islam in Banten and functioned as a media to spread Islam, like the 'wayang' performance performed by sunan kalijaga in Java. The latter opinion was proposed by the performer debus from Serang interviewed by Hadiningrat. (Hadiningrat, 1982:32), and it was confirmed by Nitibaskara. Nitibaskara remarks that debus started when sheikh al-madad came to Banten who intended to disseminate tarekat Qodhariyya, with its ritual actions that often include a kind of debus. He explains that it was just in the period of sultan Abul Fath Abdul Fatah (Sultan Ageng Tirtayasa), he created the traditional art debus used as a means to train and to boost the spirit of the soldiers (prajurit) of the sultanate to fight against the Dutch colonial army which was present in this period (Nitibaskara, 1993:155). 
Because both 'al-madad' and 'debus' always yell out the name of 'al-madad' before the performance, even though nowadays this action is rarely done by debus performers, some people argue that debus in Banten is the continuation of 'al-madad' in Banten, not from deboih in Aceh.

Another version claimed that al-madad which developed to become debus as we can see in practice now in Banten emerged at first in the time of Sultan Hasanuddin. Indeed, it was said that the sultan himself was its creator. He created this art performance after he found out that Bantenese people delighted in the art, especially dealing with invulnerability. (Hadiningrat, 1982:36). Hence, he created the traditional art 'al-madad' to attract attention from Bantenese society in order to convert people to Islam.

The last version of the stories about the origin of debus states that debus existed at first in the time of Sultan Ageng Tirtayasa. It was said that since he was young, Sultan Ageng Tirtayasa had been fond of different kinds of traditional art. To make his hobby useful, he often created traditional arts such as dedewaan, raket, sasaptona, (Dedewaan, raket, and sasaptona are a kind of traditional arts which are developed in Banten in Sultan Ageng Tirtayasa period) and debus, which he himself often performed. It was said that at first, he actually did not intend to create debus to show in public as a traditional art performance. He created it as a means to train and to boost the spirit of the soldiers (prajurit) of the sultanate to fight against the Dutch colonial army which was present in this period (Hadiningrat, 1982: 36,44).

Moreover, Martin van Bruinessen states that there are many indicators showing that debus first developed in the framework of tarekat. In Aceh, debus (deboih or rapa'i) is a part of the rituals of tarekat Rifa'iyah, while in Banten it deals with tarekat Qadariyya' (Bruinessen, 1995,220). However, in another article he writes that the invulnerability techniques known as debus in Banten are derived from a number of sources, but the major influence is the Rifa'iyya, the tarekat that elsewhere too (Turkey, Egypt, India) is renowned for its debuslike practices. (Bruinessen, 1995:184). This view is also proposed by Arifin. He notes that 'debus appeared at the same time with the emergence and the development of tarekat Rifa'iya'.( Arifin, 1993:1). Bruinessen ,furthermore, explains that debus in Banten is associated not only with the Qadariyya Qadariyya wa Naqsyabandiyah, to be exact -, but also other tarekats, especially Sammaniyah and Rifa'iyah.

According to J. Vredenbregt, there are only three groups of debus which are still active in Banten. All of them are located in the regency (kabupaten) 
of Serang, more specifically in the sub-regencies (kecamatan) of Walantaka, Cikande and Ciruas. They are all followers of the Qadiriya tarekat (J. Vredenbregt, 1973: 308-309).

The performance of debus in Banten is carried out by a number of performers (pemain debus) and lead by a seh debus. The instruments, also called debus, are basically the same in all three groups. They use awl-like daggers consisting of a wooden hilt with an iron spike running through it, which ends in a sharp point. During the performance, they are accompanied by music made by three large tambourines, three drums, two smaller drums (talinggit), and one rattle (ketjrek). While playing music, the performers and musicians make a profession of faith by reciting verses from the Qur'an.

A performance opens with a recitation of the surah al-Fatiha by the entire group. After this the seh invokes the special protection and assistance of his group of the prophet Muhammad, of Abd al-Kadir Jailani, and others. Then he prepares some coconut oil, water, menjan (incense) and the flowers of the kembodja. (Coconut oil and water are considered to have natural magic, therefore both of these are often used by magic performers. Furthermore, menjan (incense) and the flowers of the kembodja are considered to be the materials which are liked by the spirit, hence they are used very often for practicing magical actions). While doing so, he recites a number of verses from the Qur'an, burns some incense and performs various acts of a magical nature. Then the seh utters a number of mantera (sacred formulae) over the water, and before the performers begin the performance, they take a sip of this water. (Nakip, 2011 and J. Vredenbregt, 1973: 308-309).

The following are the actions practiced by debus performers during a performance: first are the prefatory actions of singing some songs called 'gembung,' accompanied by playing musical instruments. Second is the performance of $d z i k i r$, which is recited constantly during the rest of the performance. Third is performing beluh or mocopat, i.e. reciting prayers of adoration to God and the Prophet. Fourth is performing pencak silat (martial arts) without using any sharp objects. Fifth are the debus actions; jabbing or stabbing debus instruments into the stomach, followed by other magical actions such as breaking a coconut by using teeth, frying eggs on the head by using a stove made of the skin of coconut, cutting of parts of the body with sharp objects, burning the body, eating some pieces of glass or porcelain, climbing stairs made of sharp machete (golok tajam), etc. (Nakip, 2011 and Hadiningrat, 1982:62-66). 
The function of debus has changed. In the past, it was used for spreading Islam and for boosting the morale of the Banten soldiers fighting against the VOC. Nowadays debus functions as a traditional art performed for entertainment, not only for the local society, but also for people outside Banten, even internationally. As such it can be a media to strengthen the relationship, especially in the tourism and culture sector, between Indonesia and other countries.

\section{Conclusion}

Magic is a part of human's culture which exists not only in a primitive society, but also in the modern one. It will still exist as long as man believes that there is a great power beyond him that can influence and alter the universe.

If we look at the magical and religious reality practiced by most of the Bantenese society, it is probably caused by the impact of da'wah (religious proselytizing) conducted by the propagators (muallim or $d a^{\prime} i$ ) who, either consciously or unconsciously, tried to accommodate several Islamic teachings with local traditions that were professed by the Bantenese. Because the propagators knew that the Bantenese people were fond of occult sciences, they tried to disseminate Islam by using magical techniques. As a result, several Bantenese were interested in Islamic teachings as long as they were not seen as eliminating their local culture.

Debus, the cultivation of invulnerability to fire and sharp metal objects, is the most conspicuous representative of the magical tradition of Banten since the sultanate period until the present. In the past, this performance was used by the sultan to boost the morale of the Bantenese soldiers fighting against the VOC (Dutch East India Company). Nowadays debus functions as traditional art performed for entertainment purposes, not only for the local society, but also for people from outside Banten and even outside Indonesia.

\section{Daftar Pustaka}

Ahmad, M. Athoullah. 2005. Ilmu Hikmat di Banten, [Dissertation]. Jakarta: UIN Syarif Hidayatullah

Ali, Mufti, et.al.2007. Peran Tokoh Tarekat dalam Pemberontakan Muslim Banten 1926: Studi Kasus K.H.Abdul Hamid Ilyas Muhammad Muqri Al-Quty Labuan (1860-1959). Tela'ah. Vol 2, Nomor 5:95-110. 
Arifin, Imron. 1993. Dabus: Ilmu Kekebalan dan Kesaktian dalam Tarekat Rifa'iyah. Kasus: Pesantren Nurul haq Surabaya. Malang: Kalimasahada Press.

Bruinessen, Martin van. 1995. Kitab Kuning, Pesantren dan Tarekat: Tradisi-Tradisi Islam di Indonesia. Bandung: Mizan.

Burgel, Johann Christoph. 1988. The feather of Simurgh. The "Licit Magic" of the Arts in Medieval Islam. N.Y. and London: New York University Press.

Dhofier, Zamakhsyari.1995. The Pesantren Tradition. the Role of the Kyai in the Maintenance of Traditional Islam in Java. Arizona: Monograph Series press, Program for Southeast Asian Studiest, Arizona State University.

Dijk, Cees Van. 2005. Religious Authority: We Have Forgotten God. a paper of final Conference of the Dissemination of Religious Authority in 20 Century Indonesia Programme.

Dijk, Cees Van., 2002. Magic and Violence. Paper presented at the 13th annual workshop "European Social Science Java Network (ESSJN): Youth and Identity", Marseilles, 2-4 May 2002.

Hadiningrat, K. 1982. Kesenian Tradisional Debus. Jakarta: Proyek Media Kebudayaan Departemen Pendidikan dan Kebudayaan.

Hamka, 1980. Tasawuf Perkembangan dan Pemurniannya. Jakarta: Yayasan Nurul Islam.

Humaeni, Ayatullah. 2009. The Phenomenon of Magic in Banten Society [Thesis]. Leiden: Leiden University.

Humaeni, Ayatullah, et.al. 2010. Praktek Magis di Pesantren Salafy di Banten. [Penelitian]. Jakarta: Ditpertais Kemenag RI.

Kartodirdjo, Sartono. 1966. The Peasants' Revolt of Banten in 1888: Its Condition, Course and Sequel, 'S-Gravenhage: Martinus Nijhoff.

Mauss, Marcell. 1972. A General Theory of Magic. New York: Routledge Classics.

Nitibaskara, Tb. Ronny R. 1993. Reaksi Sosial terhadap Tersangka Dukun Teluh di Pedesaan Banten Jawa Barat (tahun 1985-1990): Studi Kasus Desa S dan A Kecamatan Sajira dan Bojonegara: (Suatu Kajian KriminologiAntropologi) [Disertasi]. Jakarta: Universitas Indonesia. 
Paguyuban keturunan P.A. Achmad Djajadiningrat. 1996. Memoar Pangeran Aria Achmad Djajadiningrat. Jakarta: Paguyuban keturunan P.A. Achmad Djajadiningrat.

Radar Banten Online. 2008. MTQ Nasional Sedot Rp 31,5 Milyar.http:// radarbanten.com $/ \bmod . p h p ?$ mod $=$ publisherËop=viewarticleEGartid=22211.[ August 28 ${ }^{\text {th } 2008] \text {. }}$

Radar Banten Online. 2007. Dijaga Polisi, Datangkan 5 Pawang, Hasilnya masih Nihil. http://radarbanten.com/mod.php? mod=publisher\&op $=$ viewarticle $\&$ artid $=12669$. [August 28 $8^{\text {th }}$ 2008].

Raffles, T.S. 1978. The History of Java. Vol II. Oxford, London \& Glasgow: Oxford University Press.

Thaifuri, Abdullah Afif. 2003. Amalan para Ulama Sala. Surabaya: Ampel Mulia.

Vredenbregt, J. 1973. Dabus in West Java. In Anthropologica. Vol XV. BKI. 129. Leiden: KITLV.

Williams, Michael C. 1982. Sickle and Crescent: The Communist Revolt of 1926 in Banten, New York: Monograph Series in Cornell Modern Indonesia Project, Southeast Asia Program.

\section{Interview}

Interview with K.H. J.M., a kyai of pesantren 'Sabilu Rosyad in Batu Kuwung, Padarincang, Banten. [interviewed on July 25 $5^{\text {th }} 2008$ ].

Interview with K.H. Ma'sum Daenury, a religious figure or ulama from Banten (Barugbug, Serang), [interviewed on August $5^{\text {th }}$ 2010].

Interview with K.H. A.S., a kyai of pesantren in Ciomas Serang Banten, [interviewed on August $5^{\text {th }}$ 2009].

Interview with Mashadi, an ex-santri of Pesantren Mambaul Huda al-Halimy, in Barugbug, Serang, Banten. [interviewed on August 23 $3^{\text {rd }}$ 2010]. 